\title{
Corporate Culture Mediates Human Resource Management Practices of Company Performance (Study of Subsidiaries and Affiliates of PT. Semen Indonesia Group)
}

\author{
Wahyu Poernomo $^{1}$, Budiyanto ${ }^{2}$, Suhermin $^{3}$ \\ ${ }^{1}$ Students of Doctorate in Management Science, \\ Sekolah Tinggi Ilmu Ekonomi Indonesia (STIESIA) Surabaya - Indonesia \\ ${ }^{2,3}$ Sekolah Tinggi Ilmu Ekonomi Indonesia (STIESIA) Surabaya - Indonesia
}

\begin{abstract}
This study aims to examine the mediating role of organizational culture consisting of clan culture, adhocracy, market, and hierarchy in mediating the influence of human resource management practices on company performance. Based on the literature used, this study developed a structural model for the observed variables, which was then tested using Structural Equation Modeling (SEM) with the help of SmartPLS version 2.0 software. The data was collected using a survey method, namely by distributing questionnaires to 166 employees who occupy two important positions, namely directors and echelon 1 who work for subsidiaries and affiliates of PT Semen Indonesia (Persero) Tbk. Group, which is taken proportionally by the total sampling method. The results showed that the practice of human resource management of PT Semen Indonesia Group has a positive influence on the performance of the company PT Semen Indonesia Group. However, this positive effect is not significant. Meanwhile, among the four types of culture observed, namely clan culture, adhocracy, market, and hierarchy, the type of culture that plays a role in mediating the influence of human resource management practices on company performance is hierarchy culture. Thus, hierarchy culture is a crucial factor that mediates the effect of human resource management practices on company performance. The findings of this study provide important implications for the theory and practice of human resource management and company performance.
\end{abstract}

Keywords - Clan Culture, Adhocracy Culture, Market Culture, Hierarchy Culture, Company Performance, Human Resource Management Practices.

\section{INTRODUCTION}

The implementation of the AFTA (Asean Free Trade Area) and the existence of the AEC, the Master Plan for the Acceleration and Expansion of Indonesia's Economic Development (MP3EI) 20112015 and the Nawa Cita program launched by President Joko Widodo and Government Regulation Number 3 of 2016 Accelerating the Implementation of the National Strategic Project triggers domestic competition. Products that support strategic project development are also affected by the phenomenon in Asia and within the country, including increased cement competition, because almost all infrastructure development projects require cement as a supporting product. Positive estimation of the increasing demand for cement products in Indonesia will become an opportunity for new players to enter. In addition to being an opportunity for new entrants, positive estimates of the increasing demand for cement also encourage existing players to improve the quality of business performance and production capacity. PT Semen Indonesia is a cement company with the largest production capacity in Indonesia.

At present, PT Semen Indonesia, which has the initial name of PT Semen Gresik, has 20 subsidiaries and affiliates. The change of name to PT Semen Indonesia was carried out in 2012, which was the first step in implementing the company's strategy in forming the Strategic Holding Group to synergize all operational activities and maximize all of its potential to ensure optimal operational and financial performance. The change from PT Semen Gresik to PT Semen Indonesia is expected to improve the quality of business performance and production capacity in order to remain able to become a market leader in the competitive market competition map, the fact is not working as expected.

Another fact that represents a decline in the performance of PT Semen Indonesia due to the intense competition of cement producers in Indonesia, which can clearly be seen in the continued decline in profitability of the company 
from 2013 to 2015 even though PT Semen Indonesia is in the position of being a market leader. Profitability cannot be used as the sole reference in evaluating company performance (Rivai \& Sagala, 2009: 595), but profitability is one important measure that can explain the health of a company (Onibala, Tommy, and Van Rate, 2014).

Company performance can be understood as an overall picture that displays the state of the company at a certain time (Rivai \& Sagala, 2009: 604). Company performance can be influenced by several things, including knowledge management (knowledge management), namely knowledge transfer (Rhodes et al, 2008), the development of innovative capabilities, and innovative processes (Rhodes et al, 2008; Gavrea \& Ilies, 2011), strategy, information technology, external environment (Gavrea \& Ilies, 2011; Kim \& Jee, 2007; Ibrahim \& Primiama, 2015), internal environment (Ibrahim \& Primiama, 2015), structure, quality, performance measurement, corporate governance (Gavrea \& Ilies , 2011), employees (human resources) and human resource management (Rose \& Kumar, 2006; Melinda, 2006; Gavrea \& Ilies, 2011), innovative organizational culture (Rhodes et al, 2008; Rose \& Kumar, 2006).

The many determinants of company performance require companies to conduct evaluations and improvements in the corporate environment. Theory-Based Theory, developed by Edith Penrose (1959) (Gottschalk, 2007: 89), asserts that a company, or organization, or work group unit, can achieve success or success, in the sense of achieving strategic goals set, is the result of a large contribution from internal company factors, specifically mentioned as human resource factors (Wan, Hoskisson, Short, \& Yiu, 2011).

Human resource management scientific experts, overall agreed that to be able to maximize the existence of human resources to be able to carry out these roles in accordance with the company's strategy requires a touch of management on the part of the company (Griffin, 2003: 122). The practice of human resource management is carried out with the principle that human resources are the most important assets of the company that must be managed as well as possible, supported by the establishment of regulations and company policies that facilitate this orientation, and without ignoring the existence of other factors to try to synergize the functions of each human resource become a corporate operational unit in order to achieve company goals (Hamid, 2014: 27).

In an empirical review, the role of human resource management practices in supporting company success has been proven by many previous researchers, including by Zehir et al., (2016) Ferguson and Reio Jr., (2010); Kim and Ployhart, (2014); Hanci-Donmez and Karacay, (2019); Buller and McEvoy, (2012); Katou, (2008);
Melinda, (2006) who found that the practice of human resource management has a significant influence on company performance. The development of human resources in the company is not only focused on increasing competency, but also on managing knowledge and mindset of human resources in the company. Thus, human resources in the company will be able to support the company's performance.

Analysis of human resource management practices and company performance is actually a research concept that is generally researched, however, based on the results of previous research conducted, it was found that the measurement of company performance that is generally done only using traditional measurement methods, which only use financial perspectives only in describe the overall performance of the company. Rivai \& Sagala (2009:595) state that traditional company performance measurement methods cannot explain the overall performance of the company because this method ignores other factors that also need to be measured, for example external factors, namely customer satisfaction. Therefore, the measurement of company performance needs to be done using a method that is able to explain the company's overall achievements, namely using the Balanced Scorecard method.

In addition to testing the effect of human resource management practices on company performance as measured by the Balanced Scorecard, this study will also examine the effects of other aspects of the company that also have a significant influence on company performance, namely corporate culture. There are four types of corporate culture that are able to accommodate all the characteristics of the existing corporate culture types, explained by Cameron and Quinn (in Tjahjono, 2011: 134) consisting of clan culture, adhocracy culture, market culture, and hierarchy culture. Human resource management practices known to have a connection with corporate culture, such as research conducted by Crews and Richard (2013), Kaya et al (2014), Kosiorek \& Szczepańska (2016) and Singh (2009).

The relationship between human resource management practices and corporate culture is also a general concept, however, there are still inconsistent findings that explain the connectedness model that occurs, that the majority of research results show that human resource management has a positive effect on organizational culture and company performance, but in Melinda's (2006) research conducted in Indonesia, showed different results, namely that organizational culture negatively affected company performance.

Some empirical studies that have been carried out still show gaps, both in terms of the dimensions used to measure corporate culture and company performance. In addition, variations in the 
use of measurements of human resource management practices also become obstacles for researchers in the field of human resource management, which can be seen from the focus of research which only raises some of human resource management practices, such as Rich et al. (2014) which limits studies on management practices human resources in terms of recruitment and selection, performance appraisal, training, and career management; Kim \& Ployhart (2014) who only test the effects of training and staffing.

This study aims to examine and analyze the effect of human resource management practices on company performance, clan culture in mediating the effect of human resource management practices on company performance, adhocracy culture in mediating the effect of human resource management practices on company performance, market culture in mediating the influence of management practices human resources on company performance, and cultural hierarchy in mediating the effect of human resource management practices on company performance.

\section{THEORITICAL FRAMEWORK AND HYPOTHESIS}

Resource-based view theory states that the main factor that is able to make a company survive and win in business competition is the internal factors that are owned by the company, not external factors. Internal factors referred to here are human resources in the company, which is the source of all creative ideas, problem solvers, development designers, and managers of all types of resources that exist in the company (Nothnagel, 2008: 23). Based on the theoretical framework in Figure 1, the conceptual framework for the research hypothesis can be developed as follows:

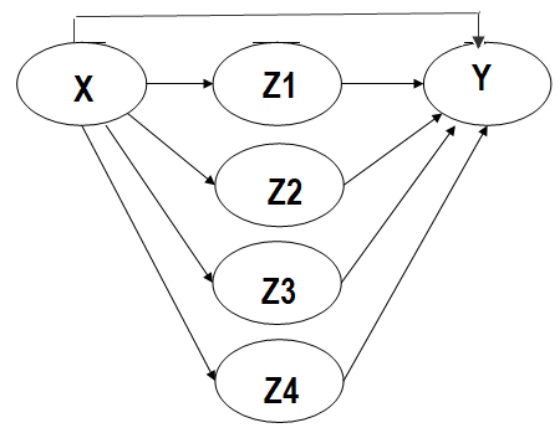

Fig 1: Research Analysis Model Source: Researchers

Remarks:

$\mathrm{X}=\mathrm{HR}$ practice, $\mathrm{Y}=$ Company Performance, $\mathrm{Z} 1=$ Clan Culture, Z2 = Adhocracyy Culture, Z3 = Market Culture, Z4 = Hierarchy Culture

The results of previous empirical studies show that human resource management practices have a positive and significant influence on performance (Zehir et.1., 2016; Ferguson and Reio
Jr., 2010; Kim and Ployhart, 2014; Hanci-Donmez and Karacay, 2019; Buller and McEvoy, 2012; Katou, 2008; Melinda, 2006). However, there are also previous empirical studies that show the results of the study suggesting that not all elements in the practice of human resources have a positive influence on company performance. Adnan et al (2011) states that participation and reward practices have a positive and significant effect on company performance; however training and development practice has a negative and significant effect; meanwhile teamwork practice has no significant effect on company performance. Seeing the picture of the results of previous studies in advance, the hypothesis of this study are:

\section{H1: There is a positive and significant influence of human resource management practices on company performance.}

Naina \& Dahlan (2008: 298) provide an explanation that corporate culture is a philosophical statement, it can function as a binding requirement for employees because it can be formally formulated in various company rules and regulations. By standardizing corporate culture as a reference to applicable rules or regulations, leaders and employees will indirectly be bound so that they can form attitudes and behaviors in accordance with the company's vision and mission and strategies so that targeted company performance will be able to be achieved.

Empirical studies conducted by Kaya et.al. (2014) and Singh (2009) who show that human resource management practices are towards clan culture. The results of research conducted by Katou (2008); Kim \& Ployhart (2014); and Melinda (2006) also added that human resource management practices have a positive and significant influence on performance, as well as empirical studies conducted by (Naranjo-Valencia et al., 2015; Lee and Kim, 2017; Acar and Acar, 2012), which states that clan culture has a positive and significant effect on company performance. By looking at the description of the results of previous studies in advance, the hypothesis of this study is:

\section{H2: Clan Culture mediates the influence of Human Resource Management Practices on Company Performance}

Adhocracy culture is a culture with an open system model, promoting flexibility and creativity that leads to growth, resources, and acquisition (Karanja, 2014). Therefore, the merits of a culture or values embedded in fostering adaptation, flexibility and creativity will be influenced by human resource management practices implemented in a company. This statement is supported by opinions expressed by Kaya et al., (2014) and Singh (2009), who in their research found that the practice of human resource management has a positive and significant influence 
on the culture of adhocracy. The company's performance itself is also known to be partially influenced both by human resource management practices (Zehir et.al., 2016; Ferguson and Reio Jr., 2010; Kim and Ployhart, 2014; Hanci-Domnmez and Karacay; 2019; Buller and McEvoy, 2012; Katou 2008 and Melinda 2006) as well as by the culture of adhocracy (Naranjo-Valencia et al., 2015; Pickles and Pickles, 2014).

H3: Adhocracy culture mediates the influence of Human Resource Management Practices on Company Performance

Market culture is a culture that places plans and goals to achieve productivity and efficiency (Karanja, 2014). In a strong culture of providing the necessary structure and control, without having to rely on a stifling formal bureaucracy that can suppress the growth of motivation and innovation, this will trigger an increase in company performance. Empirical studies conducted previously state that there is a positive and significant influence of market culture on company performance (Pickles and Pickles, 2012). The company's performance is also known to be influenced by human resource management practices (Zehir et.al., 2016; Ferguson and Reio Jr., 2010; Kim and Ployhart, 2014; HanciDomnmez and Karacay; 2019; Buller and McEvoy, 2012; Katou 2008 and Melinda 2006). In addition, human resource management practices are also known to have a significant influence on market culture (Kaya et al., 2014; Singh, 2009). Therefore, it can be said that human resource management practices can affect company performance both directly and through market culture. By looking at the description of the results of previous studies which are still relatively rare and the results are varied, the hypotheses of this study are:

H4: Market Culture mediates the influence of Human Resource Management Practices on Company Performance

Hierarchy culture emphasizes information management and communication as a means to achieve stability and control (Karanja, 2014). On the other hand, management of corporate culture, which is a stage that manages values that are designed to be a corporate culture to ensure that the process of internalization and practice of human resource management is successful so that it can improve company performance is also very necessary. This condition is supported by several studies proposed by Acar and Acar (2014) which state that the culture of hierarchy influences company performance.

Then also supported research that discusses the connectedness of human resource management practices on company performance which is shown from the results of research presented by (Zehir et.al., 2016; Ferguson and Reio Jr., 2010; Kim and Ployhart, 2014; Hanci-Domnmez and Karacay; 2019; Buller and McEvoy, 2012; Katou 2008 and Melinda 2006) which generally stated that human resource management practices affect company performance. Therefore, it can be said that the practice of human resource management can affect company performance both directly and through a culture of hierarchy. By looking at the description of previous research results which are still relatively rare and the results are varied, the hypotheses of this study are:

H5: Hierarchy Culture mediates the influence of Human Resource Management Practices on Company Performance

\section{METHODS}

This study applies a survey method that is involved by distributing questionnaires to respondents, namely employees who occupy two important positions, namely directors and echelon 1 who work at 20 subsidiaries of PT Semen Indonesia. Data collected in this study were then analyzed using structural equation modeling (SEM) with SmartPLS version 2.0 software. Meanwhile, the measurement of variables constructed as a questionnaire can be shown in table 1 below.

\section{TABLE I.}

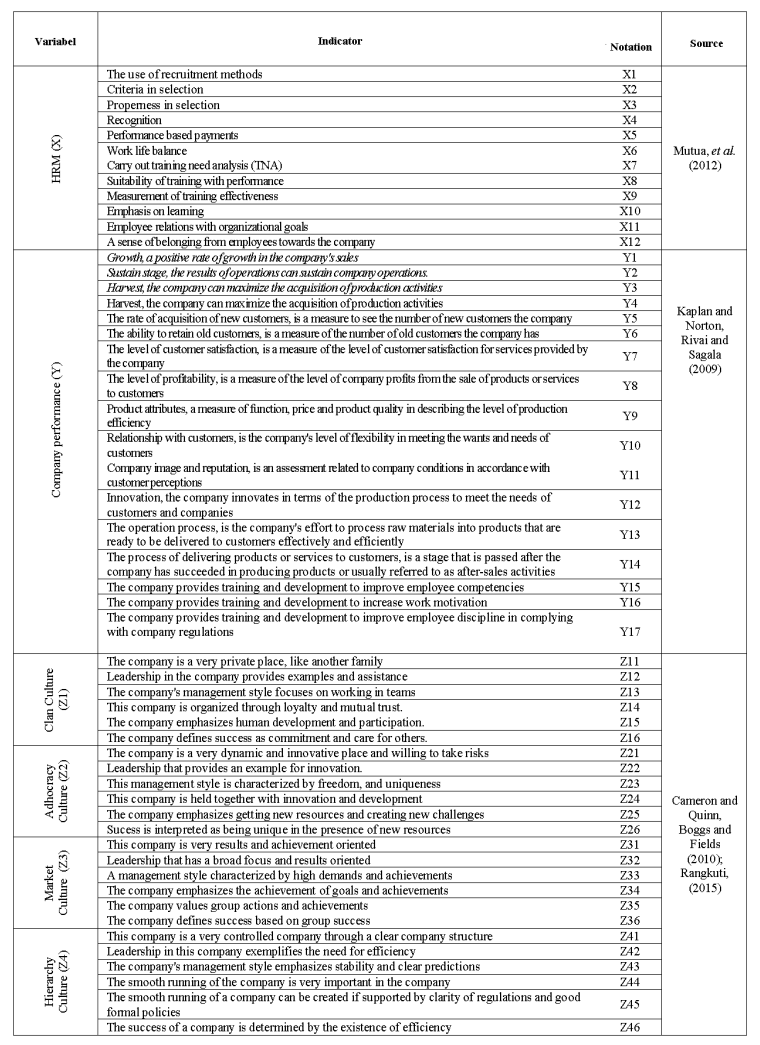

Research Instrument Grid

\section{RESULT AND DISCUSSION}

The results of the processing of SmartSmart PLS software version 2.0 shows, Inner model measurement which is a measurement of interdependent relationships between latent variables. Measurement of the inner model is done by 
evaluating the path coefficient (path coefficient) and coefficient determination. Path coefficient evaluation is used to show how strong the effect or effect of the independent variable is on the dependent variable. Based on the Inner Model Measurement picture, it can be explained that the results of the path coefficient produced indicate that the influence exerted by human resource management practices $(\mathrm{X})$ on each type of company culture and performance company (Y) is positive. Similarly, the effect of each type of culture on company performance $(\mathrm{Y})$ is positive. The greatest path coefficient value is indicated by the effect of human resource management practices (X) on clan culture (Z1) of 0.579 , then the effect of human resource management practices $(\mathrm{X})$ on adhocracy culture (Z2) of 0.574 , followed by the influence of human resource management practices $(\mathrm{X})$ to market culture $(\mathrm{Z} 3)$ of 0.561 ; the influence of human resource management practices $(\mathrm{X})$ on cultural hierarchy (Z4) of 0.573 ; and the influence of human resource management practices $(\mathrm{X})$ on company performance by 0.543 .

The type of corporate culture that has the most influence on company performance is the culture of hierarchy (Z4) of 0.409 ; followed by clan culture type $(\mathrm{Z} 1)$ of 0.161 ; market culture (Z3) of 0.033 ; and adhocracy culture (Z2) of 0.031 . Thus, the type of culture that has the most influence on company performance $(\mathrm{Y})$ is the type of culture that emphasizes clarity, rigidity, and regularity of systems and procedures in the company.

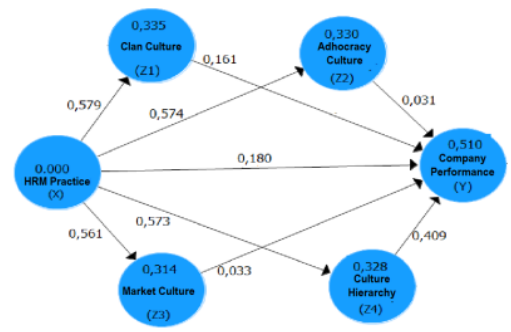

Fig 2: Inner Model Measurement

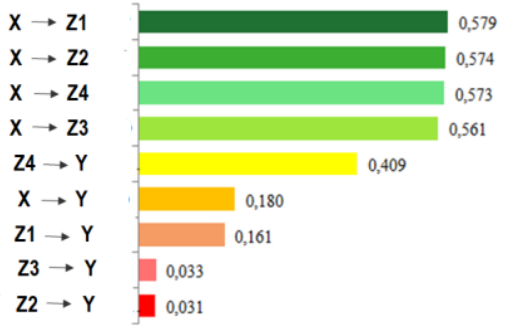

\section{Fig 3: Path Coefficient Based on High to Low} Sequence

Based on the results of these statistical tests, the verification of the hypothesis in this study can be explained as follows:

1. Based on the results of statistical tests it is known that the practice of human resource management has a positive influence on company performance.
However, this positive effect is not significant, because the path coefficient $(\beta 1)$ of 0.180 has a statistical $t$ value of 1.676 which is smaller than the specified cut off value of 1.96 ( $t$ statistics $1.676<1.96)$. Based on the results of the study which shows the absence of significant influence between human resource management practices on company performance directly, it is necessary to test other variables that can provide an explanation that there are other variables that can mediate the effect of human resource management practices on company performance.

2. This study shows that clan culture has no role in mediating the effect of human resource management practices on company performance. This is supported by statistical calculations that show that the resulting sobel value is $\beta 10$ of 1.188 with a significant value of 0.118 . The magnitude of the $\beta 10$ value is not significant, because the significant value of 0.118 is greater than the cutoff value specified ( $\alpha$ count $0.118>0.05$ ). Thus, although the practice of human resource management has a positive and significant influence on clan culture $(\beta 2=0.579$; $\mathrm{t}$ statistics $=$ $7.788>1.96)$, but the positive influence of clan culture on firm performance is not significant ( $\beta 6$ $=0.161 ; \mathrm{t}$ statistics $1.194<1.96)$. These results can be explained that the clan culture is not able to continue the positive influence given by human resource practices on clan culture to improve company performance. The results of this study are in line with previous studies that also partially test, and prove that although clan culture has a positive influence on company performance, the effect is not significant (Yesil and Rich, 2013).

3. The results of this study indicate that the culture of adhocracy does not play a role in mediating the influence of human resource management practices on company performance (sobel statistical value $\beta 11=0.207 ; \alpha$ arithmetic $0.418>$ $0.05)$. This is because although the culture of adhocracy is positively and significantly influenced by the practice of human resource management $(\beta 3=0.574 ; \mathrm{t}$ statistics $=7.246>$ 1.96), but the culture of adhocracy does not significantly affect company performance $(\beta 7=$ 0.031 ; t statistics $1.194<1,96)$. The insignificant influence of the culture of adhocracy on company performance was previously explained by an empirical study conducted by Yesil and Rich (2013) that the culture of adhocracy had a positive but not significant effect on company performance.

4. The results of this study indicate that market culture does not play a role in mediating the effect of human resource management practices on firm performance (sobel statistical value $\beta 12=0.232$; $\alpha$ arithmetic $0.408>0.05$ ). This is because although market culture is positively and significantly influenced by human resource 
management practices $(\beta 4=0.561 ; \mathrm{t}$ statistics $=$ 6.691> 1.96), market culture does not significantly affect company performance $(\beta 8=$ 0.033 ; t statistics $0.230<1,96$ ). The insignificant influence of market culture on company performance was previously explained by an empirical study conducted by Yesil and Rich (2013) that market culture has a positive but not significant effect on company performance. Thus, the results of this study enrich the empirical studies that have been carried out related to the influence of market culture on company performance, in which there are states that have positive and significant influence (Pickled and Pickled, 2012) and there are those that have negative and significant influence (NaranjoValencia et al. ., 2015; Lee and Kim, 2017).

5. The results of this study indicate that cultural hierarchy plays a role in mediating the effect of human resource management practices on company performance (statistical sobel value $\beta 13$ $=2.752 ; \alpha$ arithmetic $0.003<0.05)$. This is because hierarchy culture is positively and significantly influenced by human resource management practices $(\beta 5=0.573$; $\mathrm{t}$ statistics $=$ $6.789>1.96$ ), and hierarchy culture influences company performance positively and significantly $(\beta 8=0.409$; $t$ statistics $2.995<1,96)$. The results of this study are in line with empirical studies conducted by Acar and Acar (2014) which state that in companies in general and in public companies, cultural hierarchy has a positive and significant influence on company performance, both performance in quality, service performance, and financial performance.

\section{CONCLUSION}

Based on the results of research that has been done, the researcher can conclude that:

First, the practice of PT Semen Indonesia Group's human resource management has a positive influence on the company's performance of PT Semen Indonesia Group. However, this positive effect is not significant. The high contribution of training and the low contribution of performance management to the variable practice of company performance PT Semen Indonesia Group has the nature of supporting the insignificant influence of the variable human resource management practices on company performance in this study. That is, in practice human resource management is good, but has not been able to contribute in supporting company performance improvement. Based on the results of research showing no significant influence between human resource management practices on company performance directly, it is necessary to test other variables that can provide an explanation that there are other variables that can mediate the effect of human resource management practices on company performance.
Second, clan culture in the PT Semen Indonesia Group does not play a role in mediating the effect of human resource management practices on the company performance of PT Semen Indonesia Group. That is, clan culture is not able to continue the positive influence exerted by human resource practices on clan culture to improve company performance at PT Semen Indonesia Group. Characteristics of loyalty and mutual trust as indicators of internal clan culture in the employee's personality are not directly proportional to the company's performance indicators, namely profit growth. This is because employees who are loyal and trust each other do not necessarily contribute significantly to the achievement of company profits. Therefore, the clan's cultural characteristics ultimately do not directly affect company profitability, but rather the balance, tolerance, and comfort of relations between employees.

Third, adhocracy culture does not play a role in mediating the effect of human resource management practices on company performance at PT Semen Indonesia Group. That is, the culture of adhocracy is not able to continue the positive influence exerted by human resource practices on the culture of adhocracy to improve company performance at PT Semen Indonesia Group. Characteristics of a unique management style and provide free opportunity to argue as an indicator of internal culture adhocracy in the personal employees is not directly directly proportional to the characteristics of company performance indicators that are profit growth. This is because the unique management style and freedom of opinion within the company do not necessarily lead to activities that can directly drive the achievement of company profits. In a state-owned company, management style that emphasizes the existence of activities that inspire and motivate employees in constructive and creative activities, does not show a significant correlation with the company's financial performance.

Fourth, market culture has no role in mediating the effect of human resource management practices on company performance at PT Semen Indonesia Group. That is, market culture is not able to continue the positive influence exerted by human resource practices on market culture to improve company performance at PT Semen Indonesia Group. The insignificance of this influence could be due to the group's achievements not necessarily reflecting the company's achievements. Market culture is known to prioritize business competition as an orientation to the creation of corporate values. So as to create a very thick competitive atmosphere, both against business competitors and within the company's internal scope. Thus there will be differences in industry performance based on the performance of each group. The difference in performance occurs because each group has a different level of effectiveness.

Fifth, hierarchy culture plays a role in mediating the influence of human resource 
management practices on company performance at PT Semen Indonesia Group. It means that the culture of hierarchy is able to continue the positive influence given by the practice of human resources to the culture of hierarchy to improve company performance at PT Semen Indonesia Group. When a company has a leader who provides clear decisions, the existence of regulatory standards and procedures, controll, and accountability mechanisms that are valued and valued as the key to success, formalized standards, there is a clear work structure then all members of the organization can be controlled by work procedures, so as to maintain or maintain the organization so that it can move smoothly. Thus, the smooth running of the company with the support of clarity of regulations and policies will improve the performance of the company, especially in terms of achieving company profits.

\section{REFERENCES}

[1] Acar, Z., \& Acar, P. 2012. The Effects Of Organizational Culture And Innovativeness On Business Performance In Healthcare Industry. Procedia - Social and Behavioral Sciences.

[2] Adnan, Zurina., Hazman Shah Abdullahb \& Jasmine Ahmad. 2011. Direct Influence of Human Resource Management Practices on Financial Performance in Malaysian R\&D Companies. World Review of Business Research. Vol. 1. No. 3.

[3] Buller, Paul F. \& Glenn M. McEvoy. 2012. Strategy, human resource management and performance: Sharpening line of sight. Human Resource Management Review.

[4] Boggs, W. B., \& Fields, D. L. 2010. Exploring Organizational Culture And Performance Of Christian Churches. International Journal Of Organizational Theory And Behavior, Vol. 13, No. 3, 305-334.

[5] Crews, Derek \& Scherron Richard. 2015. Aligning Culture with Human Resource Strategies. International Journal of Business and Social Science Vol. 4 No. 15 [Special Issue].

[6] Fatihudin, D., Jusni \& M. Mochklas. 2018. HOW MEASURING FINANCIAL PERFORMANCE. International Journal of Civil Engineering and Technology (IJCIET), 9 (6):553-557

[7] Ferguson, Karen L. \& Thomas G. Reio Jr. 2010. Human Resource Management Systems And Firm Performance. Journal of Management Development. Vol. 29 No. 5, 2010 pp. 471-494

[8] Gottschalk, P.2007. CIO And Corporate Strategic Management: Chaning Role Of CIO To CEO. London: Idea Group.

[9] Gavrea, Corina; Ilies, Liviu; \& Stegerean, Roxana. 201). Determinants of Organizational Performance : The Case of Romania. Management \& Marketing Challenges for The Knowledge Society. Vol 6 (2). $285-300$.

[10] Griffin, R. W. 2003. Manajemen, Jilid 1, Edisi 7. Jakarta: Erlangga.

[11] Hanci-Donmez, Tugce \& Gaye Karacay. 2019. HighPerformance Human Resource Practices and Firm Performance: Mediating Effect of Corporate Entrepreneurship. International Journal of Organizational Leadership.

[12] Hamid, S. 2014. Manajemen Sumber Daya Manusia Lanjutan. Yogyakarta: Deepublish.Karanja, Joy Wangui. 2014. Effects of Corporate Culture on Organization Performance. IOSR Journal of Mathematics (IOSR-JM) Volume 10, Issue 6 Ver. II.

[13] Katou, A. A. 2008. Measuring The Impact Of HRM On Organisational Performance. Journal Of Industrial Engineering And Management, Vol. 1, No. 2, 119-142.

[14] Kaya, N., Ergun, E., \& Kesen, M. 2014. The Effects Of Human Resource Management Practices And Organizational Culture Type On Organizational Cynisicm:
An Empirical Study In Turkey. British Journal Of Art And Social Sciences, Vol. 17, No. 1, 43-61.

[15] Kosiorek, Dariusz \& Dynamic Consulting Katarzyna Szczepańska. 2016. Relationships between organisational culture and human resource management. Jagiellonian Journal of Management. vol. 2, no. 3, pp. 205-215.

[16] Kim, Y., \& Ployhart, R. E. 2014. The Effect Of Staffing And Training On Firm Productivity And Profit Growth Before, During, And After The Great Recession. Journal Of Applied Psychology, Vol. 99, No. 3, 361-389.

[17] Kim, M.K. \& Jee K.Y. 2007. Factors influencing strategic use of information technology and its impact on bussinessperformance of SMEs. ETRI Journl. 29(4), 497506.

[18] Lee, Myeongju \& Hyunok Kim. 2017. Exploring the Organizational Culture's Moderating Role of Effects of Corporate Social Responsibility (CSR) on Firm Performance: Focused on Corporate. Contributions in Korea.. Sustainability.

[19] Melinda, T. 2006. Pengaruh Perilaku Pimpinan Dan Praktik Manajemen Sumber Daya Manusia Terhadap Budaya Organisasi Dan Kinerja Bank Perkreditan Rakyat Di Jawa Timur. Jurnal Widya Manajemen dan Akuntansi, Vol. 6, No. 2, Agustus, 195-211.

[20] Mochklas,M., Panggayudi, D.S., \& Soenarto. 2019. THE WORK CULTURE OF SOUTH KOREAN COMPANIES IN INDONESIA. Humanities \& Social Sciences Reviews, 7(4):603-60. https://doi.org/10.18510/hssr.2019.7480

[21] Mutua, S.M., Karanja, K., \& Namusonge, G. S. 2012. Role of Human Resources Management Practice on Performance of Financial Cooperative Based in Nairoby County, Kenya. International Journal of Humanities and Social Science, Vol. 2, No.22,November, 289-297.

[22] Naranjo-Valencia, Julia C., Daniel Jiménez-Jiménez \& Raquel Sanz-Valle. 2015. Studying the links between organizational culture, innovation, and performance in Spanish companies.Revista Latinoamericana de Psicología.

[23] Naina, Akhmadsyah \& M Alwi Dahlan. 2008.Manusia Komunikasi, Komunikasi Manusia: 75 Tahun $M$. AlwiDahlan. Jakarta: Penerbit Buku Kompas

[24] Onibala, I. R., Tommy, P., \& Van Rate, P. Analisis Rasio Profitabilitas dan Risiko Keuangan Terhadap Harga Saham Xl Axiata Tbk Yang Terdaftar Di Bei Periode 2007-2012. Jurnal Emba, Vol. 2, No. 1, 374-384.

[25] Rangkuti, F. 2015. Swot Balanced Scorecard: teknik menyusun strategi korporat yang efektif plus cara mengelola kinerja dan risiko. Jakarta : PT Gramedia Pustaka Utama.

[26] Rivai, V., dan Sagala, E. J. 2009. Manajemen Sumber Daya Manusia Untuk Perusahaan: Dari Teori Ke Praktik, Edisi Kedua. Jakarta: PT Raja Grafindo Persada.

[27] Rhodes, J., et al. 2008. Factors influencing organizational knowledge transfer: implication for corporate performance. Journal of Knowledge Management, 12 (3): $84-100$.

[28] Singh, A. K. 2010. A Study Of Hrm Practices And Organizational Culture In Selected Private Sector Organization In India. Acta Oeconomica Pragensia, Vol. 18, No. 4, 64-80.

[29] Tjahjono, H. 2011. Culture Based Leadership: Menuju Kebesaran Diri \& Organisasi Melalui Kepemimpinan Berbasiskan Budaya Dan Budaya Kinerja Tinggi. Jakarta: PT Gramedia Pustaka Utama.

[30] Wan, W. P., Hoskisson, R. E., Short, J. C., dan Yiu, D. W. 2011. Resource-Based Theory And Corporate Divesification: Accomplishments And Opportunity. Journal Of Management, Vol. 37, No. 5, September, 1335-1368.

[31] Yesil, Salih dan Ahmet Kaya. 2013. The Effect of Organizational Culture on Firm Financial Performance: Evidence from a Developing Country. Procedia - Social and Behavioral Sciences. 